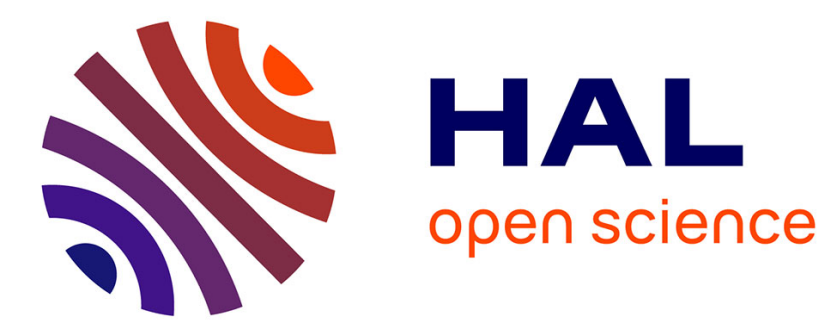

\title{
Microplastic contamination in remote alpine lakes
}

David Gateuille, Julia Dusaucy, Frédéric Gillet, Johnny Gasperi, Rachid Dris, Grégory Tourreau, Emmanuel Naffrechoux

\section{To cite this version:}

David Gateuille, Julia Dusaucy, Frédéric Gillet, Johnny Gasperi, Rachid Dris, et al.. Microplastic contamination in remote alpine lakes. EGU general assembly 2020, May 2020, VIENNE, Austria. 10.5194/egusphere-egu2020-1292 . hal-02565095

\section{HAL Id: hal-02565095 https://hal.science/hal-02565095}

Submitted on 6 May 2020

HAL is a multi-disciplinary open access archive for the deposit and dissemination of scientific research documents, whether they are published or not. The documents may come from teaching and research institutions in France or abroad, or from public or private research centers.
L'archive ouverte pluridisciplinaire HAL, est destinée au dépôt et à la diffusion de documents scientifiques de niveau recherche, publiés ou non, émanant des établissements d'enseignement et de recherche français ou étrangers, des laboratoires publics ou privés. 
EGU2020-12924, updated on 05 May 2020

https://doi.org/10.5194/egusphere-egu2020-12924

EGU General Assembly 2020

(c) Author(s) 2020. This work is distributed under

the Creative Commons Attribution 4.0 License.

\title{
Microplastic contamination in remote alpine lakes
}

\author{
David Gateuille ${ }^{1}$, Julia Dusaucy ${ }^{1}$, Frédéric Gillet ${ }^{2}$, Johnny Gaspéri ${ }^{3}$, Rachid Dris ${ }^{4}$, Grégory \\ Tourreau ${ }^{5}$, and Emmanuel Naffrechoux ${ }^{1}$ \\ ${ }^{1}$ USMB, Le Bourget du Lac cedex, France (david.gateuille@univ-smb.fr) \\ ${ }^{2}$ ONG Aqualti, Chambery, France \\ ${ }^{3}$ GERS-LEE, Univ Gustave Eiffel, IFSTTAR, Bouguenais, France \\ ${ }^{4}$ UPEC, Créteil, France \\ ${ }^{5}$ SIALIS Ingénierie, Bellenglise, France
}

Since their first detection in the 1970s, microplastics have been a growing concern in public opinion. Although a large number of studies are interested in this contamination, the fate of microplastics in freshwater remains poorly understood. In particular, the identification of sources, the degradation processes of these compounds and their impacts on aquatic ecosystems constitute fields of research to be investigated. PLASTILAC is the first project focusing on the presence and fate of microplastics in 4 remote alpine lakes (Muzelle Lake, Vert Lake, Pormenaz Lake and Anterne Lake) that have been investigated during summer 2019. The aims of this study were to better understand the microplastic dynamics in small remote lake catchment and to quantify the impacts of various anthropic activities on the microplastic contamination.

The lakes were chosen to allow the comparison of the different transfer processes occurring at the catchment scale. Thus, the lakes of Muzelle and Anterne have similar sizes (about $10000 \mathrm{~m}^{2}$ ) and altitudes (about $2100 \mathrm{~m}$ a.s.l). These two lakes are isolated and have no direct access apart from several hour hikes. They are however separated by a distance of about $120 \mathrm{~km}$. A comparison of their contamination levels therefore makes it possible to assess the background contamination at the scale of the Northern Alps. On the contrary, the Anterne, Pormenaz and Vert Lakes are very close but cover a wide gradient of altitude (from 1260 to $2100 \mathrm{~m}$ a.s.l.) and of exposure to anthropogenic activities. Their comparison allows us to study the influence of distance from potential sources on the microplastic contamination.

To investigate the dynamics of microplastics at the lake basin scale, a multi-compartment approach was implemented. The water column was sampled using a specially designed boat that allowed the filtration of the large volumes (approximately 200 cubic meters) of water required in lightly contaminated environments. The boat was equipped with a $50 \mu \mathrm{m}$ mesh. A similar system was used to sample the lake outlets and determine the outflows of microplastics. In order to quantify the incoming flows, an atmospheric fallout collector was also installed. Finally, lake sediments were collected to quantify the fraction of microplastics eliminated from the water column through sedimentation. All of these data made it possible to establish a mass balance of microplastics at the scale of the watershed of lakes and to determine the characteristic times of 


\section{contamination.}

Although analyzes are still in progress, the first results show that even the most distant lakes from anthropogenic sources have significant microplastic contamination of the order of 1 particle per cubic meter. Due to the distance to the sources, the microplastic pollution was constituted fibers while fragments and micro-beads could not be observed. 